\title{
Experimental investigation on the performance of an air-to-air energy recovery for building applications in hot-humid climate
}

\author{
M.F. Zafirah and A. Mardiana* \\ Energy, Indoor and Environmental Quality Research Group, School of Industrial \\ Technology, Universiti Sains Malaysia, 11800 USM, Pulau Pinang, MALAYSIA \\ *Email: mardianaidayu@usm.my \\ Phone: +6046532214; Fax: +6046536375
}

\begin{abstract}
The aim of this study was to evaluate the performance of an air-to-air energy recovery system in terms of latent efficiency and recovered energy. Experimental investigations were carried out under controlled conditions in Energy and IEQ Testing Unit located in School of Industrial Technology, Universiti Sains Malaysia. Tests were performed under different airflow rates ranged from 1.0 to $3.0 \mathrm{~m} / \mathrm{s}$ and intake relative humidity of $70 \%$, $80 \%$ and $90 \%$. The latent efficiency and recovered energy of the system were calculated and evaluated by adopting calculation method by ASHRAE Standard. The latent efficiency of this system ranged from 40 to $74 \%$ and the highest value of recovered energy of $1,456 \mathrm{~W}$ was achieved at $2.5 \mathrm{~m} / \mathrm{s}$ and $90 \%$. Results indicate that the latent efficiency decreased and in contrast the recovered energy increased with increasing airflow rates.
\end{abstract}

Keywords: Air-to-air energy recovery, performance, hot-humid climate, experimental investigation

\section{INTRODUCTION}

Over the past century, there has been a dramatic increase in energy consumption of the world's energy usage. This phenomenon has resulted in the global rising pattern in building energy consumption reaching figures between $20 \%$ and $40 \%$ (Fan, \& Ito, 2012). The main factors contribute to this increasing trend include:(i) the growing numbers in population; (ii) the higher demand for building services; (iii) the essentials for better comfort levels; and (iv) longer duration of time spent by people inside buildings [1]. Besides, energy usage for heating, ventilation and air-conditioning systems (HVAC) by building sector accounts about 40 to $50 \%$ of the total final energy demand [1]. It is predicted that these HVAC systems will continue to take a huge amount of total energy consumption in buildings as stated in [2]. Without any precautions taken into consideration, the upraising trend in energy demand will continue to increase in the future. Thus, improving energy efficiency in buildings becomes a prime objective for global energy policymakers nowadays. Thus, it is essential that technologies to reduce energy usage are designed to have the maximum impact of energy saving [3]. With this concern, air-to-air energy recovery system appears as one of the key solutions to produce energy saving [4]. According to Pavel [5], the application of air-to-air energy recovery system basically helps in reducing the energy impacts by $45 \%$ besides providing fresh outdoor air to an indoor space. Furthermore, the system also aids in reducing the level of indoor air contamination by providing a consistent and reliable level of ventilation, setting the 
occupants in control of their indoor air conditions [6]. The system has been approved as one of the energy-efficient technologies that can save a large portion of thermal load since heat or energy would be transferred from the warmer airstream [5, 7].

The air-to-air energy recovery system is a mechanical system that operates based on a process of recovering energy (heat/mass) from a stream at a high temperature to a low-temperature stream through a core (heat exchanger) to maintain a comfortable temperature of indoor spaces [8]. The system able to remove polluted air from indoor spaces and replaces it with fresh outdoor air. In general, there are two general classifications of air-to-air energy recovery system; i) sensible air-to-air energy recovery system and; ii) total air-to-air energy recovery system [9-14]. Thorough reviews on airto-air energy recovery technologies are reported in $[9,15]$. Based on the reviews, a lot of works has been conducted with regard to numerical, simulation and experimental approaches of the system. However, a gap still exists between research results and practical applications and therefore, future investigation should be established in these areas to better evaluate the feasibility and reliability of the system in building services. Besides, most studies reported that the application of this system was prevalently designed for cold climate area $[5,16,17]$. This could be mainly because most studies in the field of air-to-air energy recovery system only focus on the countries with both summer and winter season $[8,18]$. Only several studies can be found in the open literature pertaining to the application of this system in hot-humid climate [19] and most of them merely based on numerical study $[20,21]$ and lack of experimental approaches $[19,22$, 23]. Thus, to close this gap, this study proposed a design of an air-to-air energy recovery system for potential application in hot-humid climate. Performance of the system in terms of efficiency and recovered energy was investigated and evaluated based on experimental approach.

\section{METHODOLOGY}

In this study, an air-to-air energy recovery core was developed and formed based on hydrophilic polymeric membrane layers. It was structured with 23 pieces of waveform stand channels, arranged in a cross-flow manner and with the capabilities to transfer both heat and moisture simultaneously. This configuration also allowed air to change direction in a manner that ensures sufficient air comes in contact with heat transfer surface prior leaving the core. The dimensions of the core were $0.2 \mathrm{~m}$ height, $0.2 \mathrm{~m}$ length and $0.1 \mathrm{~m}$ width with $0.002 \mathrm{~m}$ height of sinusoidal plate fin channels. A core shell was designed to house the core at the centre with two separate flexible air ducts (intake and exhaust) with a diameter of $0.015 \mathrm{~m}$. The shell was made of $0.025 \mathrm{~m}$ thick polystyrene sandwich panels with thin aluminium sheet for insulation purpose. The shell helped to station and separate two airstreams (intake and exhaust) of the core (Figure 1). Two DC centrifugal fans with a maximum of $24 \mathrm{~V}$ were installed in the intake and exhaust ducts to assist airflow and distribute the air through the air-to-air energy recovery system. The air-to-air energy recovery system was designed to recover energy in hot-humid climate with the design parameters of: i) airflow ranged from 300 to $60,000 \mathrm{~m}^{3} / \mathrm{h}$; ii) intake temperatures ranged from 30 to $45^{\circ} \mathrm{C}$; room temperatures ranged from 20 to $25^{\circ} \mathrm{C}$.

An air-to-air energy recovery system was tested in a controlled experimental chamber comprised of an indoor space with a dimension of $2.9 \mathrm{~m} \times 4.6 \mathrm{~m} \times 5 \mathrm{~m}$, an insulated controlled test room with a dimension of $2 \mathrm{~m} \times 2 \mathrm{~m} \times 2 \mathrm{~m}$, located in School of Industrial Technology, Universiti Sains Malaysia (Figure 2). The insulated test room was made of $0.045 \mathrm{~m}$ polyurethane foam sandwich panel to reduce the influence of 
surroundings. An artificial heating system was used to generate heat in the test room. Meanwhile, air-conditioning equipment was placed to simulate cold temperature in the room. Measurements were carried out under different airflow rates ranged from 1.0 to $3.0 \mathrm{~m} / \mathrm{s}$ using an established method by [24] as stated in [25].

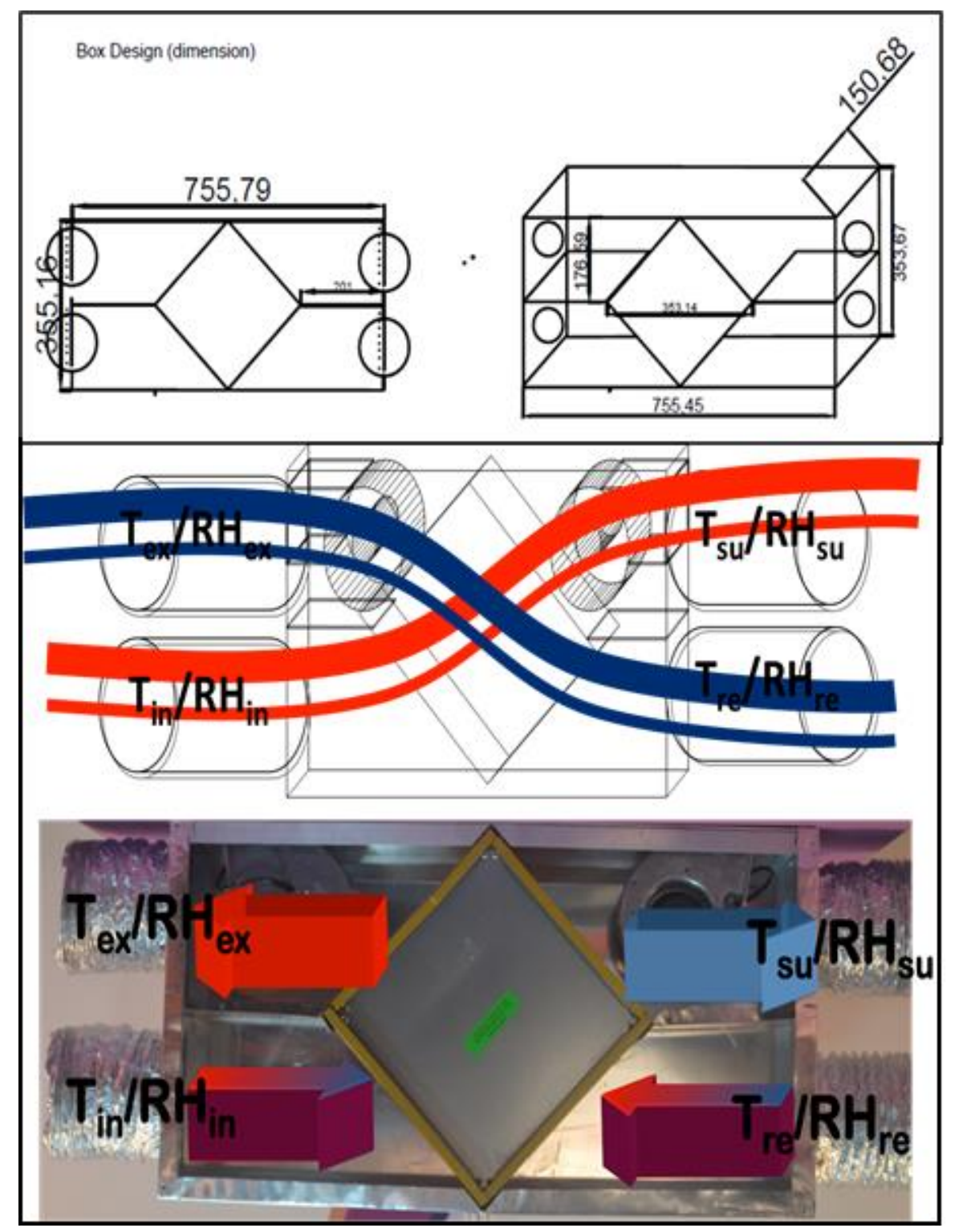

Figure 1. Design of an air-to-air energy recovery system

In order to test the efficiency of the system at different airflows, two speed controllers were connected to the DC centrifugal fans. Intake relative humidity before entering core $\left(\mathrm{RH}_{\mathrm{i}}\right)$, intake relative humidity after entering core $\left(\mathrm{RH}_{\mathrm{s}}\right)$, return relative humidity $\left(\mathrm{RH}_{\mathrm{r}}\right)$ and exhaust relative humidity after entering core $\left(\mathrm{RH}_{\mathrm{e}}\right)$ were recorded using Delta Ohm HD9817T1 dual sensor $\left(+/-0.21^{\circ} \mathrm{C}\right.$ or $\left.+/-2.5 \%\right)$ and were placed at four (4) different points across the experimental chamber. Connection of a Hobo Data Receiver ZW-RCVR ( temp: -20 to $50^{\circ} \mathrm{C}$ and RH: 5 to $95 \%$ ) with a unit of Hobo ZW003 Temperature/Relative humidity $(\mathrm{RH})$ data $\left( \pm 0.54{ }^{\circ} \mathrm{C}\right.$ and $\left.\pm 2.5 \%\right)$ was placed to measure the room (R) conditions. Four thermocouples were positioned in the controlled test room, and five thermocouples were placed in the indoor space. For airflow 
measurements, a hot-wire anemometer ( $\pm 3 \%$ of reading, $\pm 0.05 \mathrm{~m} / \mathrm{s}$ ) $0.05 \mathrm{~m} / \mathrm{s}$ was used to measure airflow rates of intake and exhaust airstreams at the same points of relative humidity measurement. Log-Tchebycheff method was applied in order to obtain accurate airflow rate values [26]. For each test, the experimental chamber was allowed to come to steady-state condition, which was attained after 45 minutes. The measurements were then performed after the experimental chamber reached the steady-state condition. Data was recorded using a data acquisition system comprising DT800 with DeLogger ${ }^{\mathrm{TM}} 5$ Pro Software and was collected over a period of two (2) h for each test. Results were analysed to evaluate the efficiency and recovered energy of the system by adopting calculation method as suggested by ASHRAE Standard [9, 13, 27]. The tests were carried out at mean room conditions: temperature $=24^{\circ} \mathrm{C}$; relative humidity $=52 \%$ and mean intake relative humidity $\left(\mathrm{RH}_{\mathrm{i}}\right)$ of $70 \%, 80 \%$ and $90 \%$ with intake temperature $\mathrm{T}_{\mathrm{i}}$ fixed at $35^{\circ} \mathrm{C}$.

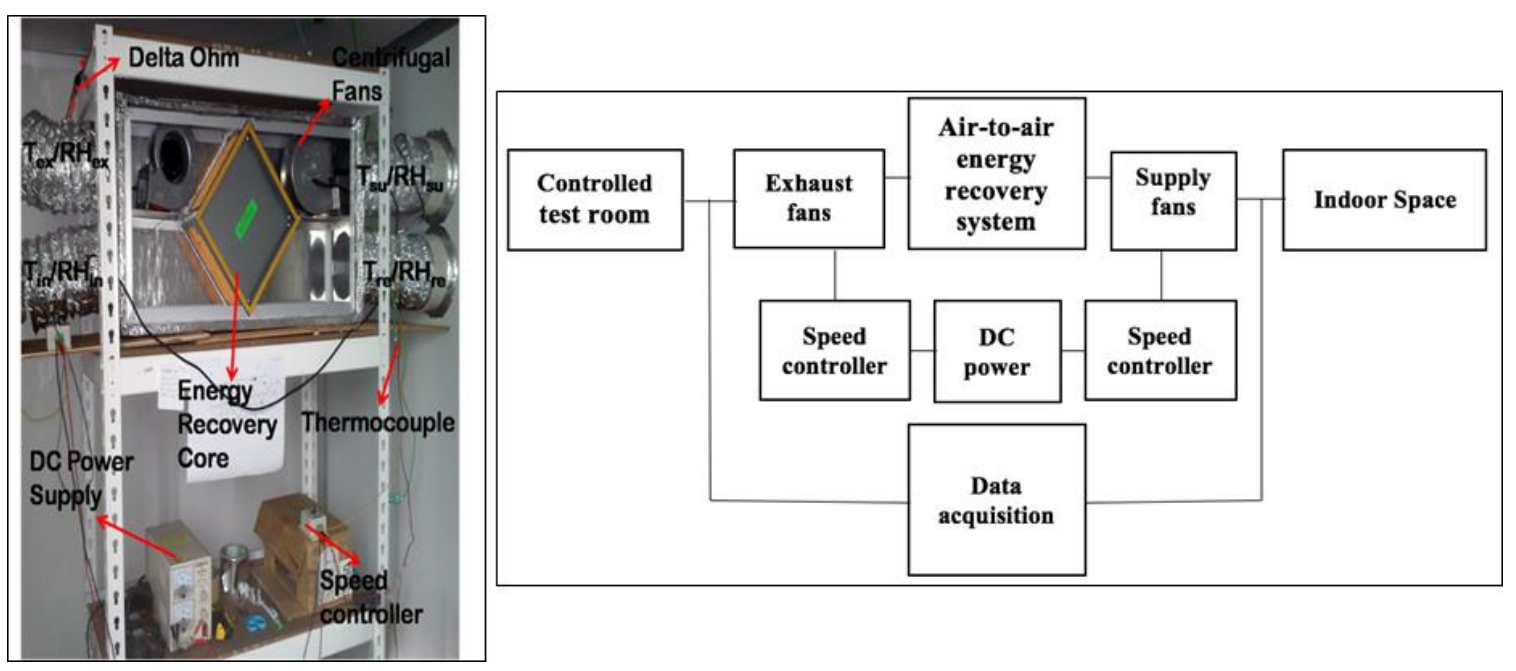

Figure 2. Experimental set up

\section{RESULTS AND DISCUSSION}

Table 1, 2 and 3 show the measured and calculated data of the air-to-air energy recovery system at mean intake mean intake relative humidity $\left(\mathrm{RH}_{\mathrm{i}}\right)$ of $70 \%, 80 \%$ and $90 \%$ with intake temperature constant at $35^{\circ} \mathrm{C}$, respectively for airflow rate ranged from 1.0 to 3.0 $\mathrm{m} / \mathrm{s}\left(0.018-0.054 \mathrm{~m}^{3} / \mathrm{s}\right)$. From this data, it was calculated that the relative humidity difference $(\Delta \mathrm{RH})$ at intake relative humidity $70 \%$ was $3.75 \%$, at $80 \%$ was $4.12 \%$ and at $90 \%$ was $3.75 \%$ for airflow rate of $1.0 \mathrm{~m} / \mathrm{s}\left(0.018 \mathrm{~m}^{3} / \mathrm{s}\right)$. On the other hand, at airflow rate of $3.0 \mathrm{~m} / \mathrm{s}\left(0.054 \mathrm{~m}^{3} / \mathrm{s}\right), \Delta \mathrm{RH}$ was found to be in a range of 1.30 to $3.05 \%$.

Table 1. Measured and calculated data at $70{ }^{\circ} \mathrm{C}$.

\begin{tabular}{ccrcccc}
\hline $\begin{array}{c}\text { Intake air } \\
\text { velocity, } \mathrm{V}_{\mathrm{i}} \\
(\mathrm{m} / \mathrm{s})\end{array}$ & $\begin{array}{c}\text { Volumetric } \\
\text { airflow rate, } \mathrm{Q}_{\mathrm{i}} \\
\left(\mathrm{m}^{3} / \mathrm{s}\right)\end{array}$ & $\begin{array}{c}\text { Mass air } \\
\text { flow rate, } \mathrm{M}_{\mathrm{a}} \\
(\mathrm{kg} / \mathrm{s})\end{array}$ & $\begin{array}{c}\mathrm{RH}_{\mathrm{i}} \\
(\%)\end{array}$ & $\begin{array}{c}\mathrm{RH}_{\mathrm{s}} \\
(\%)\end{array}$ & $\begin{array}{c}\mathrm{RH}_{\mathrm{r}} \\
(\%)\end{array}$ & $\begin{array}{c}\mathrm{RH}_{\mathrm{e}} \\
(\%)\end{array}$ \\
\hline 1.0 & 0.018 & 0.021 & 69.93 & 66.18 & 58.32 & 54.16 \\
1.5 & 0.027 & 0.031 & 70.30 & 67.48 & 53.08 & 49.41 \\
2.0 & 0.036 & 0.041 & 70.05 & 68.23 & 50.00 & 46.16 \\
2.5 & 0.045 & 0.052 & 69.50 & 65.69 & 55.89 & 57.79 \\
3.0 & 0.054 & 0.062 & 70.26 & 68.96 & 56.34 & 54.16 \\
\hline
\end{tabular}


Table 2. Measured and calculated data at $80{ }^{\circ} \mathrm{C}$.

\begin{tabular}{ccccccc}
\hline $\begin{array}{c}\text { Intake air } \\
\text { velocity, } \mathrm{V}_{\mathrm{i}} \\
(\mathrm{m} / \mathrm{s})\end{array}$ & $\begin{array}{c}\text { Volumetric } \\
\text { airflow rate, } \\
\left(\mathrm{m}^{3} / \mathrm{s}\right)\end{array}$ & $\begin{array}{c}\text { Mass air } \\
\text { flow rate, } \\
\mathrm{M}_{\mathrm{a}}(\mathrm{kg} / \mathrm{s})\end{array}$ & $\begin{array}{c}\mathrm{RH}_{\mathrm{i}} \\
(\%)\end{array}$ & $\begin{array}{c}\mathrm{RH}_{\mathrm{s}} \\
(\%)\end{array}$ & $\begin{array}{c}\mathrm{RH}_{\mathrm{r}} \\
(\%)\end{array}$ & $\begin{array}{c}\mathrm{RH}_{\mathrm{e}} \\
(\%)\end{array}$ \\
\hline 1.0 & 0.018 & 0.021 & 80.32 & 76.20 & 56.87 & 73.54 \\
1.5 & 0.027 & 0.031 & 80.10 & 74.82 & 55.33 & 55.57 \\
2.0 & 0.036 & 0.041 & 79.91 & 74.06 & 55.99 & 65.56 \\
2.5 & 0.045 & 0.052 & 81.81 & 76.94 & 55.86 & 65.32 \\
3.0 & 0.054 & 0.062 & 80.57 & 78.99 & 60.63 & 69.19 \\
\hline
\end{tabular}

Table 3. Measured and calculated data at $90{ }^{\circ} \mathrm{C}$.

\begin{tabular}{ccccccc}
\hline $\begin{array}{c}\text { Intake air } \\
\text { velocity, } \\
(\mathrm{m} / \mathrm{s})\end{array}$ & $\begin{array}{c}\text { Volumetric } \\
\text { airflow rate, } \\
\left(\mathrm{m}^{3} / \mathrm{s}\right)\end{array}$ & $\begin{array}{c}\text { Mass air } \\
\text { flow rate, } \mathrm{M}_{\mathrm{a}} \\
(\mathrm{kg} / \mathrm{s})\end{array}$ & $\begin{array}{c}\mathrm{RH}_{\mathrm{i}} \\
(\%)\end{array}$ & $\begin{array}{c}\mathrm{RH}_{\mathrm{s}} \\
(\%)\end{array}$ & $\begin{array}{c}\mathrm{RH}_{\mathrm{r}} \\
(\%)\end{array}$ & $\begin{array}{c}\mathrm{RH}_{\mathrm{e}} \\
(\%)\end{array}$ \\
\hline 1.0 & 0.018 & 0.021 & 91.00 & 87.25 & 63.64 & 79.76 \\
1.5 & 0.027 & 0.031 & 90.16 & 82.25 & 58.39 & 69.13 \\
2.0 & 0.036 & 0.041 & 89.51 & 84.89 & 65.36 & 67.28 \\
2.5 & 0.045 & 0.052 & 90.22 & 83.13 & 58.13 & 72.06 \\
3.0 & 0.054 & 0.061 & 90.23 & 87.18 & 57.04 & 72.67 \\
\hline
\end{tabular}

Figure 3 illustrates the efficiencies of the system based on the measured for airflow rates $\left(\mathrm{V}_{\mathrm{i}}\right)$ ranged from 1.0 to $3.0 \mathrm{~m} / \mathrm{s}\left(\mathrm{Q}_{\mathrm{i}}=0.018\right.$ to $\left.0.054 \mathrm{~m}^{3} / \mathrm{s}\right)$ and tested intake relative humidity $\left(\mathrm{RH}_{\mathrm{i}}\right)$ of $70 \%, 80 \%$ and $90 \%$. From the figure, it can be seen efficiency decreased with increasing airflow rates for every tested relative humidity. The relationship between efficiency and airflow rates at 70\%,80\% and $90 \%$ can be expressed by equation (1), (2) and (3), respectively.

$$
\begin{aligned}
& y=-6.3 x+77.5 \\
& y=-3.0 x+65.0 \\
& y=-5.2 x+69.2
\end{aligned}
$$

This trend can be explained by a theory of residence time within the air-to-air energy recovery core, which is the average amount of time that a substance (air) spends in the core. The higher the residence time, the higher is the efficiency [26]. In contrast, efficiency decreases with increasing relative humidity. The efficiency ranged from 40 to $74 \%$. The highest efficiency $(74 \%)$ was achieved at $0.018 \mathrm{~m}^{3} / \mathrm{s}$ and $70 \%$. Meanwhile, the lower efficiency was achieved at $\left(0.054 \mathrm{~m}^{3} / \mathrm{s}\right)$ and $90 \%$. Thus, intake air conditions give significant effects to the performance in terms of efficiency of energy recovery system as suggested in [28, 29]. In additional, the material properties of the air-to-air energy recovery have been claimed having significant impact on latent efficiency [30]. The variations of recovered energy with airflow rates are shown in Figure 4 for airflow rates $\left(\mathrm{V}_{\mathrm{i}}\right)$ ranged from 1.0 to $3.0 \mathrm{~m} / \mathrm{s}$ and tested intake relative humidity $\left(\mathrm{RH}_{\mathrm{i}}\right)$ of $70 \%, 80 \%$ and $90 \%$. From the study, it was found that the recovered energy of air-to-air energy recovery system increased with increasing airflow rates. The highest value of recovered energy of 1,456 W was achieved at $2.5 \mathrm{~m} / \mathrm{s}$ and the lowest value was achieved at $1.0 \mathrm{~m} / \mathrm{s}$ for intake relative humidity of $90 \%$. Whilst, for intake relative humidity of $70 \%$, the lowest value of recovered energy of $531 \mathrm{~W}$ was obtained at $1.0 \mathrm{~m} / \mathrm{s}$ and the highest value 
was obtained at $2.5 \mathrm{~m} / \mathrm{s}$. From these results, it was observed that the higher humidity difference between the indoor and outdoor gives the higher amount of recovered energy [30].

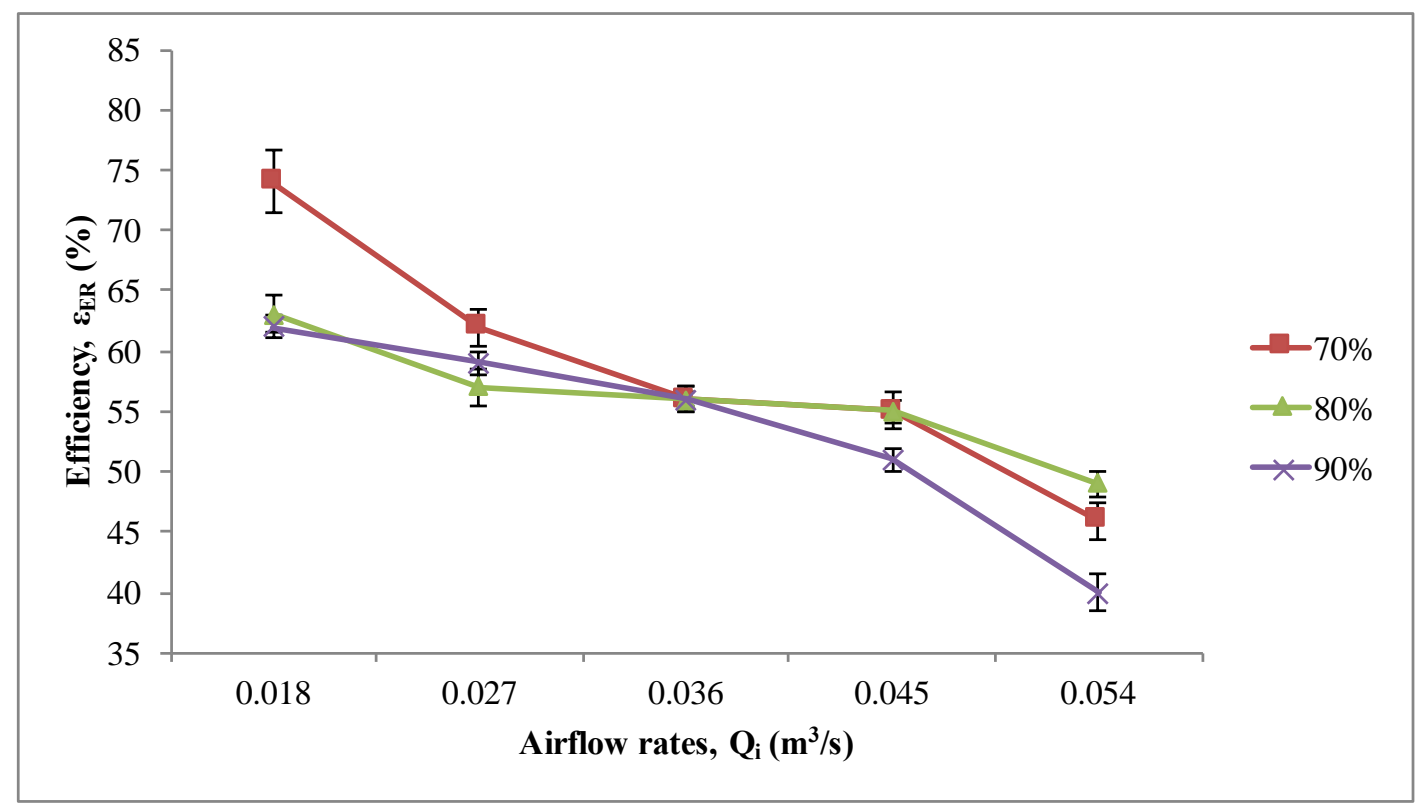

Figure 3. Efficiency of the system versus airflow rate

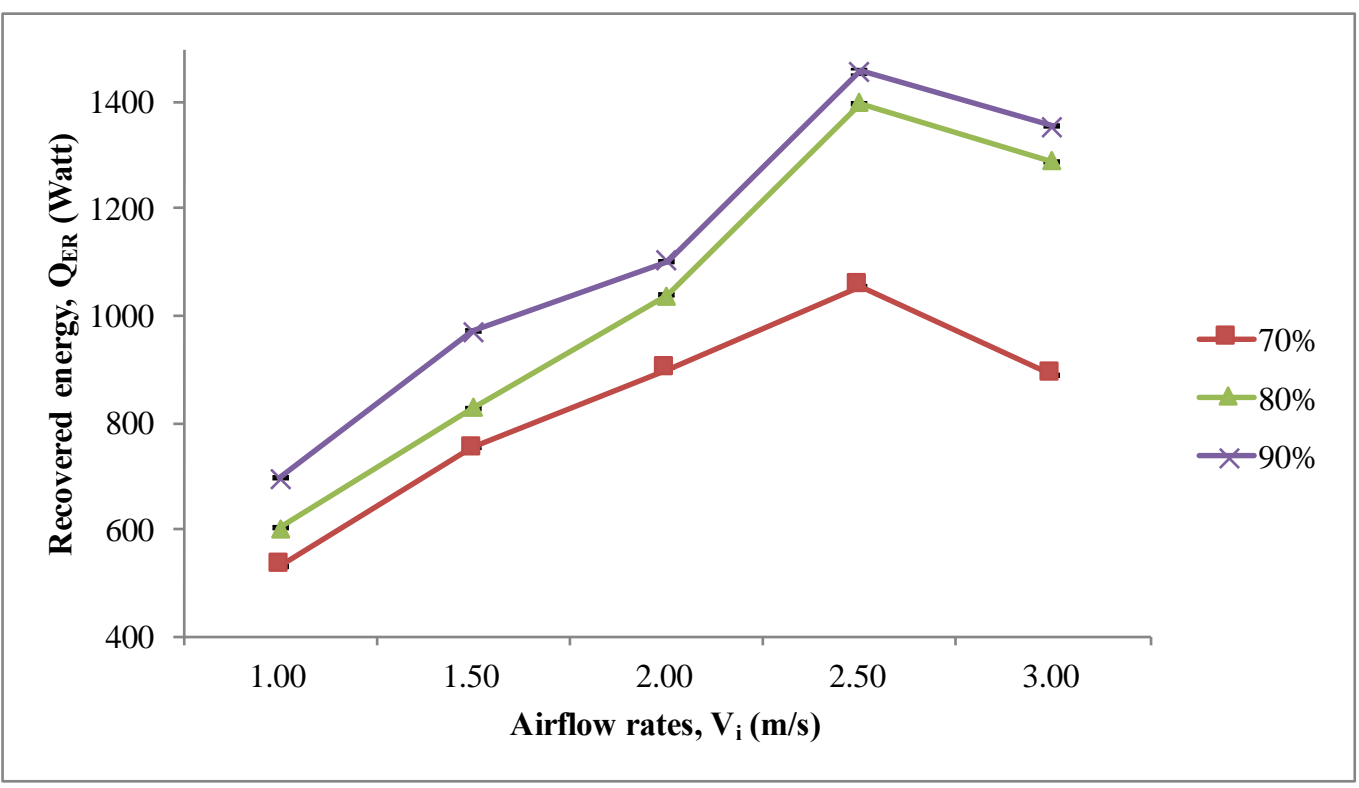

Figure 4. Recovered energy of the system

\section{CONCLUSIONS}

The air-to-air energy recovery system was completely designed and tested to evaluate the performance of the system in terms of efficiency and recovered energy. In order to achieve its objectives, a series of experimental investigations were carried out at room condition of $24^{\circ} \mathrm{C}$ and $52 \%$ and intake relative humidity $\left(\mathrm{RH}_{\mathrm{i}}\right)$ of $70 \%, 80 \%$ and $90 \%$ in School of Industrial Technology, Universiti Sains Malaysia. It was found that the 
efficiency of the system decreased with increasing airflow rates and relative humidity. Meanwhile, when the airflow rate increased, the recovered energy increased. The efficiency of the system ranged from 40 to $74 \%$ with the highest recovered energy of $1,456 \mathrm{~W}$. Thus, as a conclusion, the performance of the system was affected by the intake air conditions.

\section{ACKNOWLEDGMENTS}

The authors wish to express their acknowledgements to MOHE ERGS Grant (203/PTEKIND/6730116) and USM RUI Grant (1001/PTEKIND/814275) for the financial support associated with this study. The first author also would like to thank Universiti Malaysia Pahang and Ministry of Education Malaysia for SLAB Fellowship Scheme of her postgraduate study.

\section{REFERENCES}

[1] Chua K, Chou S, Yang W, Yan J. Achieving better energy-efficient air conditioning-a review of technologies and strategies. Applied Energy. 2013;104:87-104.

[2] Gong G, Zeng W, Wang L, Wu C. A new heat recovery technique for airconditioning/heat-pump system. Applied Thermal Engineering. 2008;28:2360-70.

[3] Zafirah M, Mardiana A. Design, efficiency and recovered energy of an air-to-air energy recovery system for building applications in hot-humid climate. International Journal of Scientific Research. 2014;3:1803-7.

[4] Shao L, Riffat S. Flow loss caused by heat pipes in natural ventilation stacks. Applied thermal engineering. 1997;17:393-9.

[5] Pavel S. Efficiency of heat recovery unit in D-building: Mikkeli University of Applied Sciences; 2010.

[6] Fauchoux MT, Simonson CJ, Torvi DA. The effect of energy recovery on perceived air quality, energy consumption, and the economics of an office building. ASHRAE Transactions. 2007;113.

[7] Masitah A, Ahmad MI, Yatim Y. Heat Transfer and effectiveness analysis of a cross-flow heat exchanger for potential energy recovery applications in hot-humid climate. Energy Research Journal. 2015;6:7.

[8] Liu D, Zhao F-Y, Tang G-F. Active low-grade energy recovery potential for building energy conservation. Renewable and Sustainable Energy Reviews. 2010;14:2736-47.

[9] Mardiana A, Riffat S. Review on physical and performance parameters of heat recovery systems for building applications. Renewable and Sustainable Energy Reviews. 2013;28:174-90.

[10] Seyed-Ahmadi M, Erb B, Simonson CJ, Besant RW. Transient behavior of runaround heat and moisture exchanger system. Part I: Model formulation and verification. International Journal of Heat and Mass Transfer. 2009;52:6000-11.

[11] Shao L, Riffat S, Gan G. Heat recovery with low pressure loss for natural veltilation. Energy and Buildings. 1998;28:179-84.

[12] Lazzarin RM, Gasparella A. Technical and economical analysis of heat recovery in building ventilation systems. Applied Thermal Engineering. 1998;18:47-67.

[13] Riffat S, Gan G. Determination of effectiveness of heat-pipe heat recovery for naturally-ventilated buildings. Applied Thermal Engineering. 1998;18:121-30. 
[14] Lamb B. Plate heat exchangers - a low-cost route to heat recovery. Journal of Heat Recovery Systems. 1982;2:247-55.

[15] Mardiana-Idayu A, Riffat S. Review on heat recovery technologies for building applications. Renewable and Sustainable Energy Reviews. 2012;16:1241-55.

[16] Pandey S, Nema V. Investigation of the performance parameters of an experimental plate heat exchanger in single phase flow. International Journal of Energy Engineering. 2011;1:19-24.

[17] Kragh J, Rose J, Nielsen TR, Svendsen S. New counter flow heat exchanger designed for ventilation systems in cold climates. Energy and Buildings. 2007;39:1151-8.

[18] Zhou Y, Wu J, Wang R. Performance of energy recovery ventilator with various weathers and temperature set-points. Energy and Buildings. 2007;39:1202-10.

[19] Delfani S, Pasdarshahri H, Karami M. Experimental investigation of heat recovery system for building air conditioning in hot and humid areas. Energy and Buildings. 2012;49:62-8.

[20] Hughes BR, Chaudhry HN, Calautit JK. Passive energy recovery from natural ventilation air streams. Applied Energy. 2014;113:127-40.

[21] Fan Y, Ito K. Energy consumption analysis intended for real office space with energy recovery ventilator by integrating BES and CFD approaches. Building and Environment. 2012;52:57-67.

[22] Nasif M, Al-Waked R, Morrison G, Behnia M. Membrane heat exchanger in HVAC energy recovery systems, systems energy analysis. Energy and Buildings. 2010;42:1833-40.

[23] Niu J, Zhang L. Membrane-based energy recovery ventilators: a solution to heat recovery for ventilation air in Hong Kong. HKIE Transactions. 2001;8:58-63.

[24] Fisk WJ, Turiel I. Residential air-to-air heat exchangers: Performance energy savings, and economics. Energy and Buildings. 1983;5:197-211.

[25] Mardiana-Idayu A, Riffat SB. An experimental study on the performance of enthalpy recovery system for building applications. Energy and Buildings. 2011;43:2533-8.

[26] Zhou C. Estimation of volumetric flow rate in a square duct: Equal area versus log-Tchebycheff methods: University of Windsor; 2005.

[27] Zhang L-Z, Wang Y-Y, Wang C-L, Xiang H. Synthesis and characterization of a $\mathrm{PVA} / \mathrm{LiCl}$ blend membrane for air dehumidification. Journal of Membrane Science. 2008;308:198-206.

[28] Min J, Su M. Performance analysis of a membrane-based enthalpy exchanger: effects of the membrane properties on the exchanger performance. Journal of Membrane Science. 2010;348:376-82.

[29] Zhong K, Kang Y. Applicability of air-to-air heat recovery ventilators in China. Applied Thermal Engineering. 2009;29:830-40.

[30] Zhang L, Niu J. Energy requirements for conditioning fresh air and the long-term savings with a membrane-based energy recovery ventilator in Hong Kong. Energy. 2001;26:119-35. 